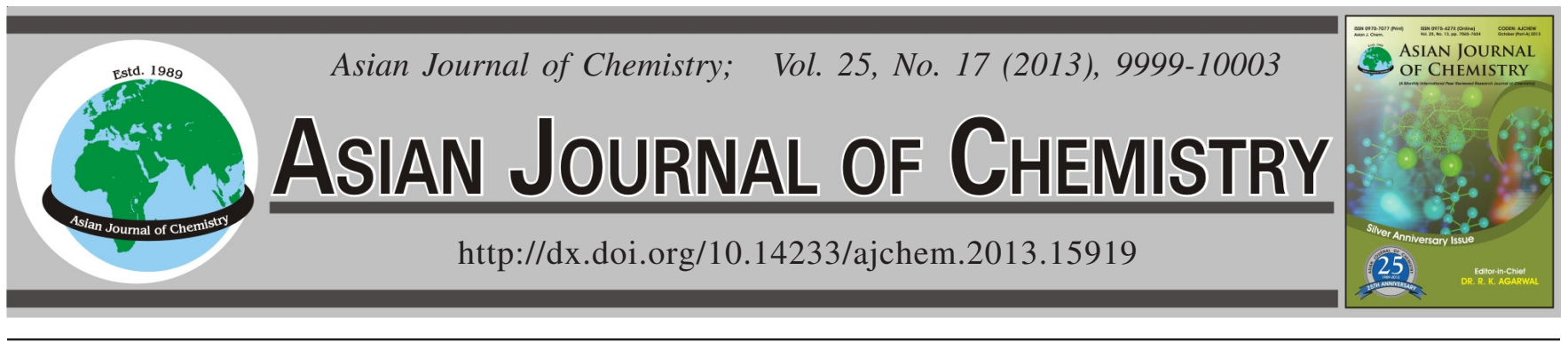

\title{
Determination of Polyhydric Phenols in Chrysanthemum by Capillary Electrophoresis with Electrochemical Detection
}

\author{
Jing Tang , Sheng Biao Zheng ${ }^{*}$ Jin-Kun Zhu, Xue Mei Zhang and Jian Fei Wang
}

Department of Science, Anhui Science and Technology University, Fengyang 233100, Anhui Province, P.R. China

*Corresponding author: E-mail: zhengtang102@163.com; yayajing@shu.edu.cn

(Received: 15 June 2013;

Accepted: 30 October 2013)

AJC-14324

\begin{abstract}
Chrysanthemum has been known for its accumulation of polyhydric phenol. These contents are important because of their nutritional and antioxidant properties. Two flavonoids (quercetin and luteolin) and chlorogenic acid were separated and determined in Chrysanthemum by capillary electrophoresis with electrochemistry detection (CE-ED). The effects of some important factors such as the potential applied to the working electrode, the concentration of the running buffer, separation voltage and injection time were investigated. Under the optimum conditions, the work electrode was a $300 \mu \mathrm{m}$ diameter carbon disk electrode and the detection potential was $+0.95 \mathrm{~V}$ (versus SCE), the analytes could be well separated within 19 min with $40 \mathrm{mmol} \mathrm{L}{ }^{-1} \mathrm{Na}_{2} \mathrm{~B}_{4} \mathrm{O}_{7}-\mathrm{H}_{3} \mathrm{BO}_{3}(\mathrm{pH} 9.2)$ as the running buffer. The response was linear over two orders of magnitude with detection limits $\left(\mathrm{S} / \mathrm{N}=3\right.$ ) ranging from $4.75 \times 10^{-7} \mathrm{~g} \mathrm{~mL}^{-1}$ to $1.04 \times 10^{-6} \mathrm{~g} \mathrm{~mL}^{-1}$. The method has been successfully applied for the analysis of real sample, with satisfactory results.
\end{abstract}

Key Words: Capillary electrophoresis, Electrochemical detection, Chrysanthemum, Polyhydric phenol.

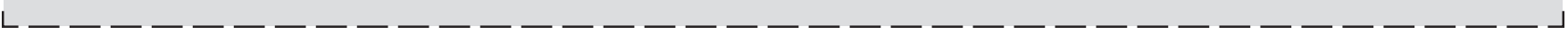

\section{INTRODUCTION}

As we know, Chrysanthemum which was described functions were soothing asthma, Mingmu, dispelling wind and heat, curing high blood pressure and heart disease. It is widely used not only as a tea drink, but also as a traditional Chinese herbal medicine. Recent studies show that the biologically active constituents of Chrysanthemum contains chlorogenic acid and abundant flavonoids, which have been reported to have the functions of antioxidation, antibacteria, antivirus, antiulcerogenic, antiinflammatory, checking cough and dispelling phlegm ${ }^{1}$. Chlorogenic acid, quercetin and luteolin (Fig. 1) are three major polyhydric phenols in Chrysanthemum, so identification and determination of the above three polyhydric phenols in Chrysanthemum will play important role to control its quality and safety for clinical applications ${ }^{2}$.

Methods for the determination of the biologically active constituents in Chrysanthemum have been reported, including the coulometric titration, ultraviolet spectrophotometry, thin-layer chromatography ${ }^{3}$, high performance liquid chromatography ${ }^{4-6}$. The coulometric titration and thin-layer chromatography have fussy operation, low sensitivity and responsibility. Ultraviolet spectrophotometry method for the determination of the total amount of the flavonoids and the chlorogenic acid in Chrysanthemum has also been developed $^{7,8}$. However, HPLC used in the analysis of traditional
Chinese medicines often has some shortcomings, including long analysis time, low resolution and short column lifetime owing to easy contamination resulting from complicated sample matrices. As a matter of fact, traditional Chinese medicines usually consist of numerous, diverse and macromolecular ingredients. Some coexisting interfering compounds can be absorbed strongly onto the packing materials of HPLC column, resulting in fast column degradation or even irreversible damage. Besides, the theoretical plate number of a HPLC column is often much lower than that of a capillary tube with the same length.

Recently, owing to its high resolving power, low solvent consumption and simple pretreatment, capillary electrophoresis (CE) has been used as an attractive method for separating and monitoring traditional Chinese medicines ${ }^{9-13}$. Previously, capillary electrophoresis has been reported to be applied for the determination of polyhydric phenol based on ultraviolet (UV) detection ${ }^{14-16}$. However, the UV detection lacks sensitivity due to the small diameter of the separation capillaries. Electrochemical detection (ED), based on the electrochemical reaction of analytes on electrode surface, provides one of the most sensitive and selective detection methods for capillary electrophoresis. Most polyhydric phenols are electroactive compounds, so CE-ED has also been employed for the determination of some polyhydric phenols in plants ${ }^{17}$.

In this work, an alternative method for the determination of chlorogenic acid, quercetin, luteolin in Chrysanthemum 


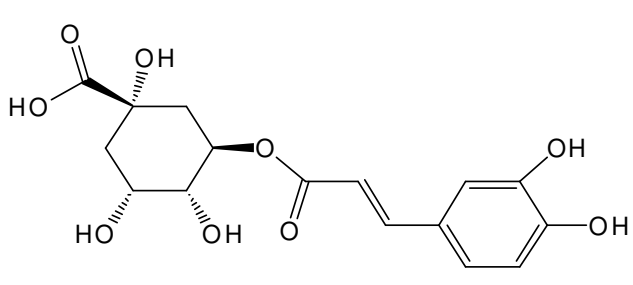<smiles>O=c1c(O)c(-c2ccc(O)c(O)c2)oc2cc(O)cc(O)c12</smiles>

Fig.1. Molecular structures of chlorogenic acid, quercetin and luteolin

by using CE-ED approach is described, which has been proven to be simple and convenient, as well as sensitive and selective.

\section{EXPERIMENTAL}

A laboratory-built CE-ED system used for analysis has been described previously (Chen, Ye, and Cheng, 2000). A \pm $30 \mathrm{kV}$ high-voltage power supply (Shanghai Institute of Nuclear Research, Shanghai, China) provided a separation voltage between the ends of the capillary. The inlet end of the capillary was held at a positive potential and the outlet end of capillary was maintained at ground. Separation capillary was an untreated fused silica capillary with $70 \mathrm{~cm} \times 25 \mu \mathrm{m}$ i.d. $\times$ $370 \mu \mathrm{m}$ o.d. (Hebei Yongnian Optic Fiber Factory, China). A pHS-3C meter (Shanghai Leici Instrument Company, Shanghai, China) was used to measure the $\mathrm{pH}$ value of the running buffer.

A pre-aligned electrochemical cell, consisting of three electrodes, a $300 \mu \mathrm{m}$ diameter carbon disc working electrode (its preparation was reported by Wang et al. ${ }^{18}$ ), a platinum auxiliary electrode and a saturated calomel electrode (SCE) as the reference electrode, was used in combination with a CHI660 electrochemical system (Shanghai Chenhua Instrument Company, Shanghai, China). Before use, the carbon disc electrode was polished with emery sand paper and sonicated in doubly distilled water and finally carefully positioned opposite the outlet of the capillary with the aid of a micromanipulator (Correct, Tokyo, Japan) and arranged in a walljet configuration ${ }^{19}$. The distance between the tip of the working electrode and the capillary outlet was as close as possible so that the capillary electrophoresis effluent directly impinged upon the electrode surface. The electropherograms were recorded using a CHI software (Shanghai Chenhua Instrument Factory, China). Capillary electrophoresis was performed in a $40 \mathrm{mmol} \mathrm{L}^{-1}$ borate buffer ( $\mathrm{pH}$ 9.2) used as the running buffer at a separation voltage of $14 \mathrm{kV}$. The potential applied to the working electrode was $+0.95 \mathrm{~V}$ ( $v s$. SCE). Samples were injected electrokinetically at $14 \mathrm{kV}$ for $6 \mathrm{~s}$.

Chlorogenic acid, quercetin and luteolin were all abtained from Chinese Chemical and Biological Drugs Institute (Beijing, China), Chrysanthemum (chuju, gongju, hangbaiju) were purchased from Bozhou drugstore, Anhui province, China. Other chemicals were analytical grade. All aqueous solutions were made up in doubly distilled water. Stock solutions of chlorogenic acid $\left(1.04 \times 10^{-3} \mathrm{~g} \mathrm{~mL}^{-1}\right)$, luteolin $(1.02 \times$ $\left.10^{-3} \mathrm{~g} \mathrm{~mL}^{-1}\right)$ and quercetin $\left(0.95 \times 10^{-3} \mathrm{~g} \mathrm{~mL}^{-1}\right)$ were prepared in anhydrous ethanol, stored in the dark at $4{ }^{\circ} \mathrm{C}$ and were diluted to the desired concentrations with the running buffer (40 mmol L-1, $\mathrm{pH}$ 9.2), The borate-phosphate running buffer was prepared by mixing $\mathrm{Na}_{2} \mathrm{~B}_{4} \mathrm{O}_{7}$ solution (concentrations ranging from 20 to $60 \mathrm{mmol} \mathrm{L}^{-1}$ ) with $\mathrm{H}_{3} \mathrm{BO}_{3}$. Before use, all solutions were filtered through $0.45 \mu \mathrm{m}$ syring filter.
Sample preparation: The air-dried Chrysanthemum (chuju, gongju, hangbaiju) (1.0 g) sample were powdered and extracted with $10 \mathrm{~mL} 99.7 \%$ ethanol in ultrasonic bath for $0.5 \mathrm{~h}$. The extract was then filtered through a filter paper. The extraction procedure was repeated three times. Next each of the samples was filtered through filter paper first and the sample was centrifuged in $1200 \mathrm{rev} / \mathrm{s}$ for $10 \mathrm{~min}$. then through a $0.45 \mu \mathrm{m}$ syringer filter. After filtered through $0.45 \mu \mathrm{m}$ syringe cellulose acetate filter, the $200 \mu \mathrm{L}$ sample was diluted with 40 $\mathrm{mmol} \mathrm{L}{ }^{-1}$ borate buffer to $1 \mathrm{~mL}$. Then it can be directly injected electrokinetically for analysis. Before use, all sample solutions were stored in the dark.

\section{RESULTS AND DISCUSSION}

Effect of the potential applied to the working electrode: Since the phenolic hydroxy groups of the three analytes can be readily oxidized electrochemically, the three analytes are electroactive and can be determined by amperometric detection. In amperometric detection the potential applied to the working electrode directly affects the sensitivity, detection limit and stability of this method. In order to obtain best detection results, optimum potential applied to the working electrode should be selected. Hydrodynamic voltammograms (HDVs) of $8.16 \mu \mathrm{g} \mathrm{mL}^{-1}$ luteolin, $41.6 \mu \mathrm{g} \mathrm{mL}^{-1}$ chlorogenic acid and $19.0 \mu \mathrm{g} \mathrm{mL}^{-1}$ quercetin are illustrated in Fig. 2. As

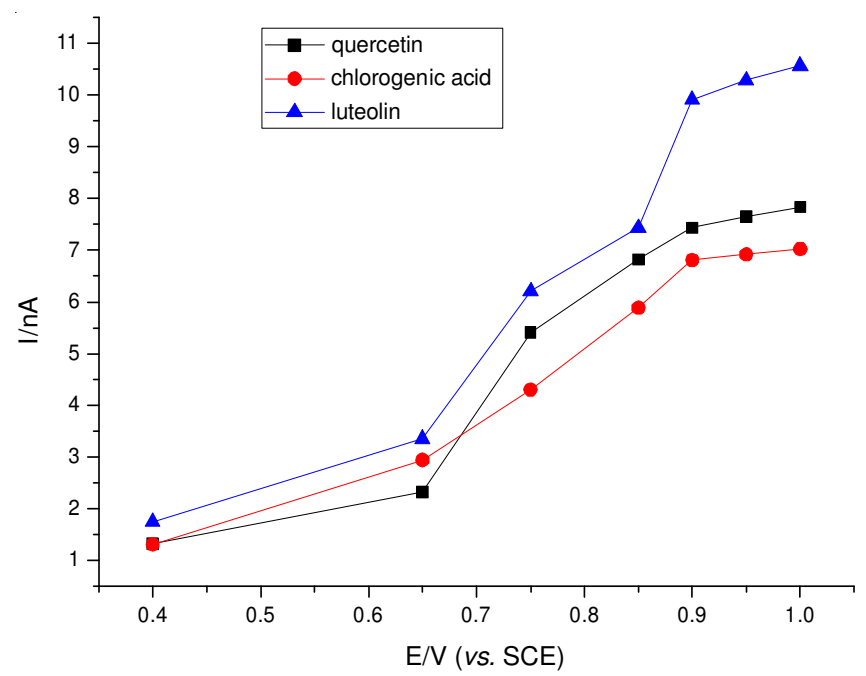

Fig. 2. Hydrodynamic voltammogram s (HDVs) for three analytes in capillary electrophoresis; Experimental conditions: fused-silica capillary, $25 \mu \mathrm{m} \times 70 \mathrm{~cm}$; working electrode, a $300 \mu \mathrm{m}$ diameter carbon disk electrode; running buffer, $40 \mathrm{mmol} \mathrm{L}^{-1}$ borate buffer $(\mathrm{pH} 9.2)$; separation voltage, $14 \mathrm{kV}$; electrokinetic injection, $6 \mathrm{~s}(14 \mathrm{kV})$; mass concentration, $8.16 \mu \mathrm{g} \mathrm{mL} \mathrm{m}^{-1}$ luteolin, $41.6 \mu \mathrm{g}$ $\mathrm{mL}^{-1}$ chlorogenic acid and $19.0 \mu \mathrm{g} \mathrm{mL}^{-1}$ quercetin 
shown in Fig. 2, when the applied potential reaches $+0.65 \mathrm{~V}$ ( $v s . \mathrm{SCE}$ ), the peak currents of three analytes increase rapidly. However, when the potential exceeds $+0.90 \mathrm{~V}$ ( vs. SCE), the current of the three analysts increases much more slowly. When the applied potential is $>+1.0 \mathrm{~V}$ ( $v s$. SCE), both the baseline noise and the background current increase very strongly, which are obviously a disadvantage for sensitive and stable detection. For a suitable compromise of high sensitivity and low background current, a value of $+0.95 \mathrm{~V}$ ( $v s$. SCE) was selected for the subsequent experiments and the background current is not too high and the $\mathrm{S} / \mathrm{N}$ ratio is the highest.

Optimum condition for separation: Alkaline borate buffer was employed in this work because the analytes can form negative-charged complexes with boric acid in alkaline solution. The acidity of the running buffer affects the zetapotential (n), the electroosmotic flow (EOF) as well as the overall charge of the analytes, which determine the migration time and the separation of the analytes ${ }^{20}$. To verify the effect of running buffer $\mathrm{pH}$ on migration behavior, experiments were performed using $40 \mathrm{mmol} \mathrm{L} \mathrm{Na}_{2} \mathrm{~B}_{4} \mathrm{O}_{7}-\mathrm{H}_{3} \mathrm{BO}_{3}$ buffer with different $\mathrm{pH}$ (range of 8.0-9.5). The results are shown in Fig. 3A. As shown in Fig. 3A, quercetin and luteolin cannot be separated at $\mathrm{pH}$ 9. When the running buffer $\mathrm{pH}$ increases, the resolution of all compounds is improved with longer migration time. At $\mathrm{pH} 9.2$ the analytes can be well separated, it is also found that the peak current is low and the peak shape becomes poor above $\mathrm{pH}$ value of 9.2. Therefore in this paper $40 \mathrm{mmol} \mathrm{L}^{-1}$ borate buffer with $\mathrm{pH} 9.2$ was chosen as the running buffer considering the sensitivity, resolution and analysis time.

Besides the $\mathrm{pH}$ value, the concentration of the running buffer is also an important parameter. It affects not only the resolution and migration time of the analytes, but also the peak current. The effect of running buffer concentration on the migration time of the analytes was also studied. Migration time and resolution increases with increasing buffer concentration as shown in Fig. 3B. However, high running buffer concentration had a negative effect on the detection limits because the peak currents of the three analytes decreased and the effect of Joule heat became more obvious. On the basis of the peak current, resolution and analysis time, $40 \mathrm{mmol} \mathrm{L}^{-1}$ borate buffer ( $\mathrm{pH}$ 9.2) was finally chosen as the optimum running buffer concentration.

The influence of separation voltage on the migration time of the analytes was also studied in this experiment. The results illustrated that the high separation voltage gave shorter migration time for all analytes. It produced more baseline noise, which resulted in higher detection limits. However, too low separation voltages would increase the analysis time considerably and cause peak broadening. Thus, the optimum separation voltage was $14 \mathrm{kV}$, at which good separation could be obtained for all analytes within 19 min (Fig. 4).

The injection time, which determines the sampling amount, affects both peak current and peak shape. The effect of injection time on capillary electrophoresis separation was investigated by changing the sampling time $(2,4,6,8,10$ $\mathrm{s}$ at a voltage of $14 \mathrm{kV}$, as shown in Fig. 5). It was found that both peak current and peak width increase with increasing sampling time. However, when the injection time was longer than $6 \mathrm{~s}$, the peak current increased slowly and the peak
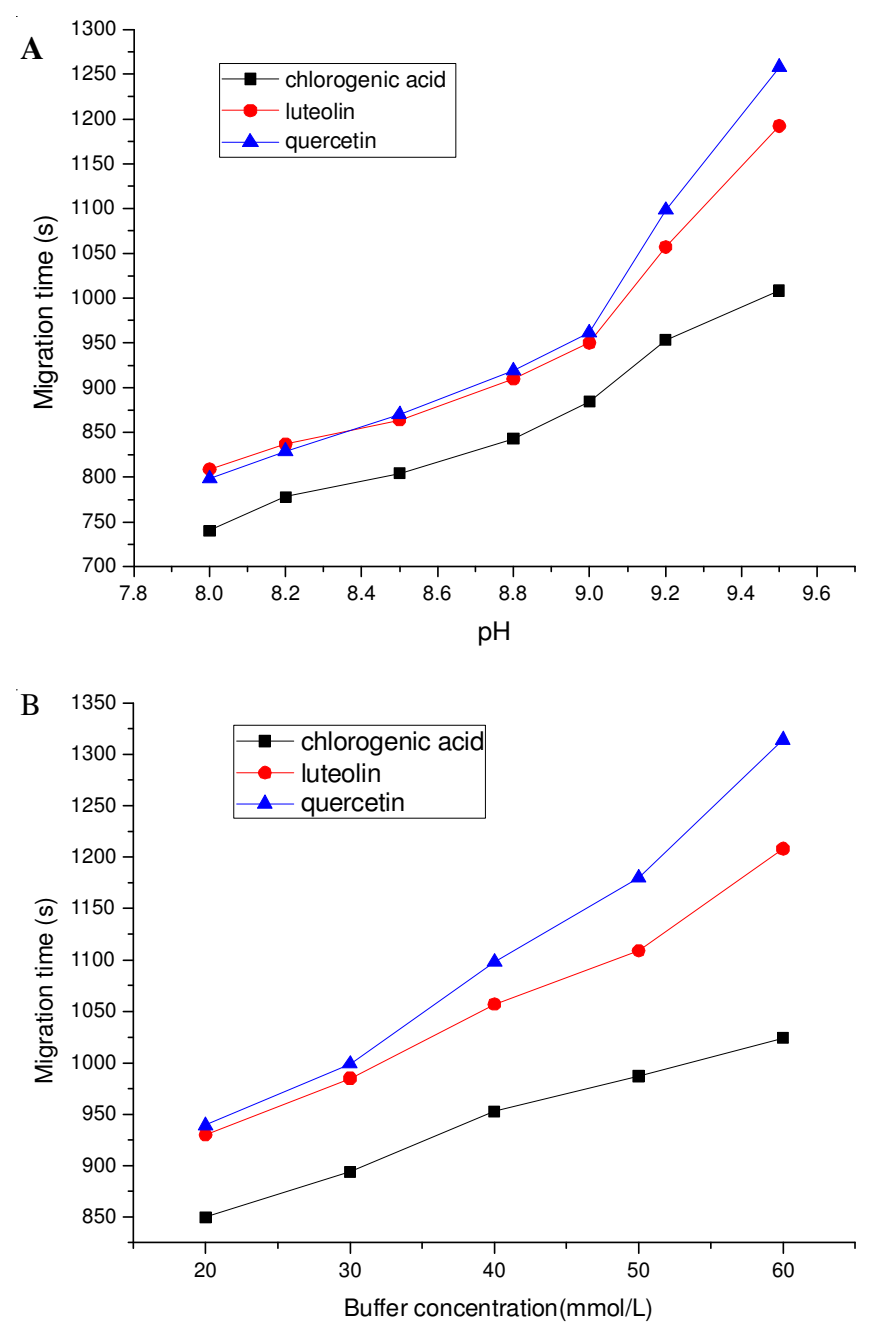

Fig. 3. Effect of buffer $\mathrm{pH}(\mathrm{a})$ and concentration(b) on the migration time of chlorogenic acid, quercetin, luteolin. Working potential: $+0.95 \mathrm{~V}$ (vs. SCE); other conditions as in Fig. 2

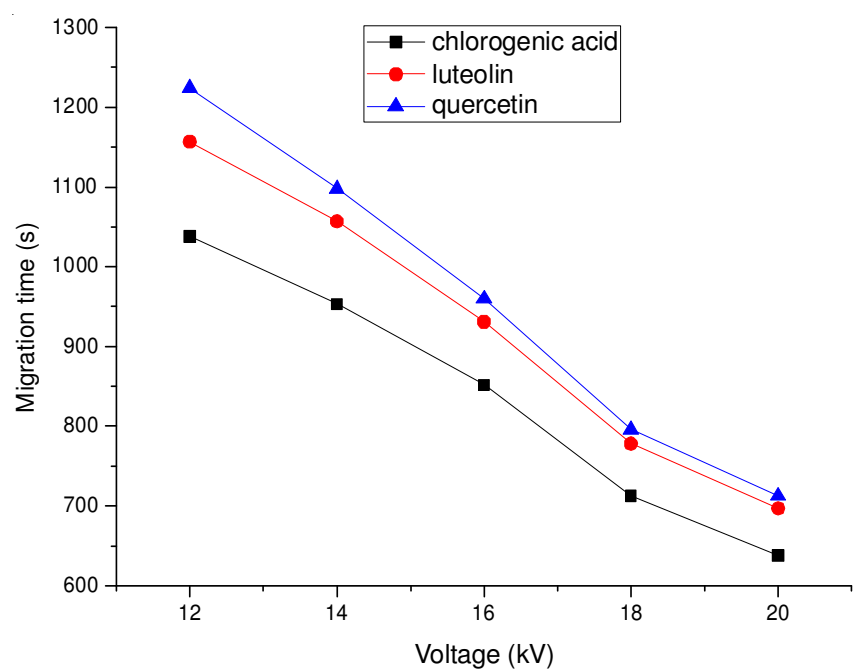

Fig. 4. Effect of voltage on the migration time of chlorogenic acid, quercetin, luteolin. Working potential: $+0.95 \mathrm{~V}$ (vs. SCE); other conditions as in Fig. 2

exhibited obvious broadening become more severe, therefore, $6 \mathrm{~s}(14 \mathrm{kV})$ was selected as the optimum injection time in this work. 


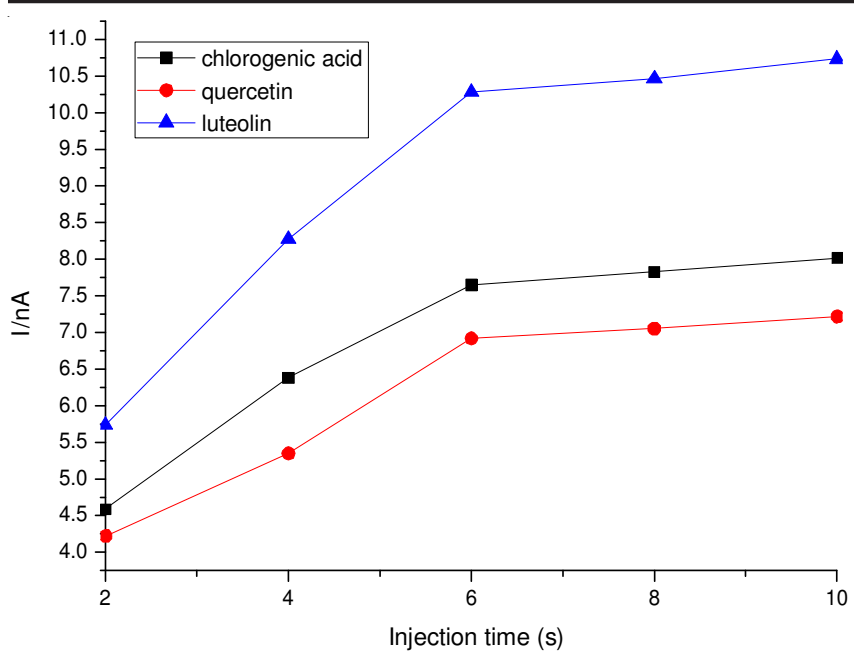

Fig. 5. Effect of injection time on the peak current of chlorogenic acid, quercetin, luteolin. Working potential: $+0.95 \mathrm{~V}$ (vs. SCE) other conditions as in Fig. 2

Repeatability, linearity and detection limits: Under the optimum condition, the repeatability of the peak current and the migration time for chlorogenic acid $\left(20.8 \mu \mathrm{g} \mathrm{mL}^{-1}\right)$, luteolin $\left(4.08 \mu \mathrm{g} \mathrm{mL}^{-1}\right)$ and quercetin $\left(9.50 \mu \mathrm{g} \mathrm{mL}^{-1}\right)$ was estimated by making repetitive injections of a standard mixture solution. The results show that the relative standard deviations (RSDs) of peak current and migration time are 3.45 and $0.47 \%$ for chlorogenic acid, 2.60 and $0.64 \%$ for luteolin and 6.95 and $0.81 \%$ for quercetin, respectively. A series of the standard mixture solutions were tested to determine the response linearity of the three analytes in this method. The detection limits are evaluated on the basis of signal-to-noise ratio of 3 and the results are presented in Table-1. The calibration curves exhibit excellent linear behavior over the concentration range of about 2 orders of magnitude for all investigated compounds.
Sample analysis and recovery: Under the optimum condition, chlorogenic acid, quercetin and luteolin in the different sample of Chrysanthemum (chuju, gongju, hangbaiju) were determined according to the procedures described earlier. Typical electropherograms obtained from dried chuju(B), gongju(C) and hangbaiju(D) are shown in Fig. 6. By comparing the migration time of analytes with the electropherogram of the standard mixture solution (Fig. 6A), the active ingredients namely chlorogenic acid (1), luteolin (2) and quercetin (3) in the different sample of Chrysanthemum can be determined. The contents of analytes in samples were calculated using their peak currents from the calibration curve under the same conditions. The comparisons of the above analytes in the different sample of Chrysanthemum are shown in Table-2. As shown in there, chlorogenic acid, quercetin and luteolin could be found and the contents of these three analytes in these three different kinds were quite different. The contents in chuju were higher than another.

Accurate amounts of chlorogenic acid, quercetin and luteolin were added to the sample solution of the different sample of Chrysanthemum and recovery was determined by standard addition method. The average recoveries and RSDs for the three analytes are listed in Table-2. The results indicated that this method was appropriate for the real sample analysis.

\section{Conclusion}

It has been demonstrated that CE-ED is characterized by high resolution and sensitivity, satisfactory stability and repeatability, low operating cost and minimal sample volume requirement. In this paper CE-ED method was successfully applied to simultaneously determine polyhydric phenol in different samples of Chrysanthemum. The electrochemical detection can provide a high selectivity since only electroactive substances can be detected. The realization of such analysis is more economical in comparison to HPLC since the

TABLE-1

REGRESSION EQUATIONS,CORRELATION COEFFICIENTS (R) AND LIMITS OF DETECTION (LOD) OF 3 COMPONENTS ${ }^{\mathrm{a}}$

\begin{tabular}{lcccc}
\hline Compound & Calibration line $\mathrm{Y}=\mathrm{aX}+\mathrm{b}^{\mathrm{b}}$ & Correlation coefficiency & Linear range $\left(\mu \mathrm{g} \mathrm{mL}^{-1}\right)$ & $\mathrm{LOD}(\mathrm{S} / \mathrm{N}=3)(\mu \mathrm{g} \mathrm{mL})^{-1}$ \\
\hline Chlorogenic acid & $\mathrm{Y}=0.1535 \mathrm{X}+0.5577$ & 0.9995 & $2.08-208$ & 1.04 \\
Luteolin & $\mathrm{Y}=0.8097 \mathrm{X}+0.3116$ & 0.9999 & $1.02-102$ & 0.204 \\
Quercetin & $\mathrm{Y}=0.4783 \mathrm{X}+0.4358$ & 0.9997 & $0.950-95.0$ & 0.475 \\
\hline
\end{tabular}

${ }^{a}$ Working potential is $+0.95 \mathrm{~V}$ ( $v s$. SCE). Other conditions are as in Fig. 2.

${ }^{\mathrm{b}} \mathrm{Y}$ and $\mathrm{X}$ are the peak current $(\mathrm{nA})$ and concentration of the analytes $\left(\mu \mathrm{gL}^{-1}\right)$.

${ }^{\mathrm{c}}$ The detection limits corresponding to concentrations giving signal-to-noise ratio of 3 .

TABLE-2

DETERMINATION RESULTS OF THE RECOVERY FOR THIS METHOD $(\mathrm{n}=3)^{\mathrm{a}}$

\begin{tabular}{|c|c|c|c|c|c|c|}
\hline Sample & Compound & Original $/\left(\mu \mathrm{g} \mathrm{mL} L^{-1}\right)$ & Spiked $/\left(\mu \mathrm{g} \mathrm{mL}^{-1}\right)$ & Found $/\left(\mu \mathrm{g} \mathrm{mL} L^{-1}\right)$ & Recovery/\% & $\mathrm{RSD} / \%$ \\
\hline \multirow[t]{3}{*}{ chuju } & Chlorogenic acid & 3.38 & 4.16 & 7.36 & 96.4 & 3.3 \\
\hline & Luteolin & 2.68 & 2.04 & 4.88 & 104 & 2.4 \\
\hline & Quercetin & 2.27 & 1.90 & 4.01 & 97.0 & 4.1 \\
\hline \multirow[t]{3}{*}{ gongju } & Chlorogenic acid & 3.62 & 4.16 & 7.54 & 98.8 & 2.8 \\
\hline & Luteolin & 2.66 & 2.04 & 4.92 & 102 & 3.6 \\
\hline & Quercetin & 2.25 & 1.90 & 4.21 & 101 & 4.9 \\
\hline \multirow[t]{3}{*}{ hangbaiju } & Chlorogenic acid & 0.39 & 4.16 & 4.38 & 99.0 & 5.3 \\
\hline & Luteolin & 1.76 & 2.04 & 3.74 & 99.2 & 2.0 \\
\hline & Quercetin & 1.84 & 1.90 & 3.85 & 103 & 1.7 \\
\hline
\end{tabular}



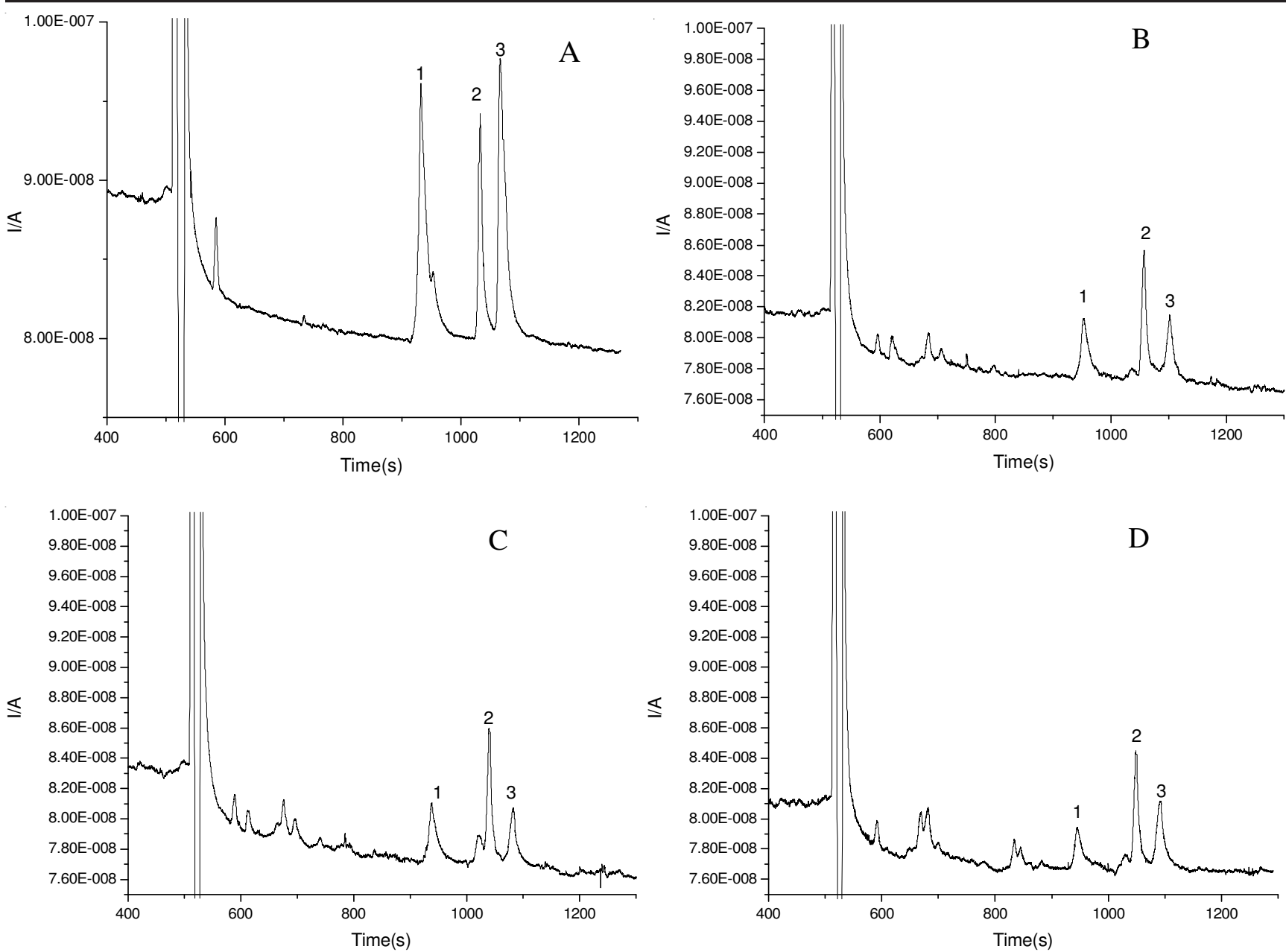

Fig. 6. Electropherograms of (A) the standard mixture solution $\left(41.6 \mu \mathrm{g} \mathrm{mL} \mathrm{L}^{-1}\right.$ chlorogenic acid, $8.16 \mu \mathrm{g} \mathrm{mL} L^{-1}$ luteolin and $19.0 \mu \mathrm{g} \mathrm{mL}^{-1}$ quercetin), samples of (B)chuju, (c)gongju and (D)hangbaiju.

Experimental conditions are the same as in Fig.1. Peaks: 1. chlorogenic acid; 2. luteolin; 3. quercetin

consumption of electrolytes is negligible and the use of organic solvents is practically avoided. It is concluded that CE-ED is a powerful technique to determine polyhydric phenol in the medicinal plants.

\section{ACKNOWLEDGEMENTS}

The authors are grateful for the financial support provided by Department of Education Anhui province (Grant No.2012SQRL147 and Grant No. KJ2013Z047).

\section{REFERENCES}

1. J.W. Jian, Q.X. Xiao, Phytomedicine Effective Component Book, People's Hygiene Press, Beijing, 1986.

2. D. Prakash, B.N. Singh and G. Upadhyay, Food Chem., 102, 1389 (2007).

3. M. Zelijam and M.S. Marica, J. Pharmacol. Biol. Anal., 24, 353 (2001).

4. H.M. Merken and G.B. Beecher, J. Chromatogr. A., 897, 177 (2000).

5. U.J. Justesen and P. Knuthsen, Food Chem., 73, 245 (2001).

6. S.P. Wang and K.J. Huang, J. Chromatogr. A.,1032 273 (2004)
7. Z.Y. Wang, X.L. Li, J. Taiyuan Univ. Technol, 35, 95 (2004).

8. X. Wei, Z.Y. Wang, Chin. J. Spectrosc. Lab., 20, 128 (2003).

9. T. Bo, X.D. Yang, K.A. Li, L.Z. Xu and H.W. Liu, J. Sep. Sci., 26, 133 (2003).

10. G.B. Li, H.Y. Zhang, Y.Q. Fan, L. Zhao and Z.D. Hu, J. Chromatogr. A, 863, 105 (1999).

11. M.C. Lee, S.J. Sheu, J. Liq. Chromatogr. Rel. Technol., 20, 63 (1997).

12. S.H. Liu, X. Tian, X.G. Chen and Z.D. Hu, J. Chromatogr. A, 928, 109 (2001).

13. L.G. Song, S.M. Zhang and Q.Y. Ou, Chromatographia, 39, 682 (1994).

14. D. Dogrukol-Ak, N. Kirimer and M. Tuncel, Anal. Lett., 34, 185 (2001).

15. Y. Sun, T. Guo, Y. Sui and F.M. Li, J. Sep. Sci., 26, 1203 (2003).

16. M.E. Yue, T.F. Jian and Y.P. Shi, Talanta, 62, 695 (2004).

17. X.J. Li, Y.P. Zhang and Z.B. Yuan, Chromatographia, 55, 243 (2002).

18. W. Wang, B. Qiu, X.Q. Xu, L. Zhang and G.N. Chen, Electrophoresis, 26, 903 (2005).

19. G. Chen, J.X. Zhang and J.N. Ye, J. Chromatogr. A, 923, 255 (2001).

20. Y.H. Cao, X. Zhang, Y.Z. Fang and J.N. Ye, Microchim. Acta, 137, 57 (2001). 